\section{N-Methyl-D-Aspartate (NMDA) Receptors}

Jose A. Rey

College of Pharmacy, Nova Southeastern

University, Ft. Lauderdale, FL, USA

\section{Definition}

The N-methyl-D-aspartate (NMDA) receptor is a tetrameric ligand-gated ion channel composed of different protein subunits, which in turn have different variants (e.g., NMDAR2A). This receptor complex is widely distributed in the mammalian central nervous system (CNS). One of the natural and most important ligands for this receptor is the excitatory amino acid neurotransmitter (EAA), and glutamate (Glu); however, other compounds, both endogenous (e.g., glycine) and exogenous (e.g., phencyclidine), may also bind to this receptor complex. The binding of l-glutamate to this voltage-dependent ionophore complex causes the opening of a cation channel for the rapid conductance of sodium and calcium into a cell. Magnesium can block the NMDA receptor's calcium channel. The NMDA receptor is unique due to the requirement of two agonists, or co-transmitters (glutamate and glycine), having to bind to the receptor complex to activate and open the calcium channel. The NMDA receptors are involved with long-term potentiation, developmental plasticity, learning, memory, and perhaps certain psychopathologies such as schizophrenia and Alzheimer's disease. Excessive stimulation of the NMDA receptor via excitotoxicity can damage and eventually lead to apoptosis (cell death) of neurons. The drug memantine is a NMDA receptor antagonist with the potential to slow down the neurodegenerative processes involved in the progression of Alzheimer's disease. The NMDA receptor will continue to be a target of significant drug development and research in the foreseeable future.

\section{References and Readings}

Brunton, L. L., Chabner, B. A., \& Knollman, B. C. (Eds.). (2011). Goodman \& Gilman's the pharmacological basis of therapeutics (12th ed.). New York: McGrawHill.

Cooper, J. R., Bloom, F. E., \& Roth, R. H. (Eds.). (2003). The biochemical basis of neuropharmacology (8th ed.). New York: Oxford University Press.

Davis, K. L., Charney, D., Coyle, J. T., \& Nermeroff, C. (Eds.). (2002). Neuropsychopharmacology: The fifth generation of progress. Philadelphia: Lippincott Williams \& Wilkins.

Stahl, S. M. (2013). Stahl's essential psychopharmacology: Neuroscientific basis and practical applications (4th ed.). New York: Cambridge University Press.

Voet, D., Voet, J. G., \& Pratt, C. W. (Eds.). (2016). Fundamentals of biochemistry: Life at the molecular level (5th ed.). Hoboken: Wiley. 